\begin{tabular}{|c|c|c|}
\hline$\overline{7}$ & $\begin{array}{c}\text { International Journal of Current Research } \\
\text { and Academic Review }\end{array}$ & 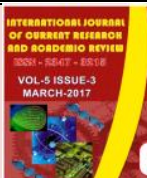 \\
\hline $\begin{array}{l}\text { EXCELLENT } \\
\text { PUBLISHERS }\end{array}$ & 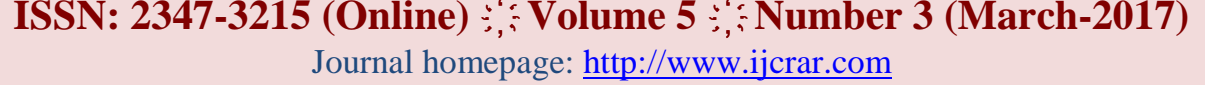 & \\
\hline
\end{tabular}

doi: https://doi.org/10.20546/ijcrar.2017.503.002

\title{
Ethnomedicinal Studies of Some Trees Growing in Punjab State, India
}

\author{
Geetanjli* \\ Department of Botany, Dev Samaj College for Women, Ferozepur City, Punjab, 152002, India \\ *Corresponding author
}

\begin{abstract}
For centuries, plants with some medicinal properties have been utilized successfully by man for the cure of common as well as chronic ailments. Traditional medicinal system has been an integral part of most of indigenous cultures all over the world. A slight set back to this medicinal system was observed in the recent past due to urbanization and advent of modern medicinal systems. However, in the past few years, traditional medicinal system has made a major comeback. During the present study, some of the trees growing in Punjab state have been investigated for their ethnomedicinal importance. It was observed that although a variety of trees growing in Punjab have been used in folk medicinal purposes, yet there is a vast scope to study more of plant resources from the state for their therapeutic values.
\end{abstract}

\section{Article Info}

Accepted: 28 February 2017

Available Online: 20 March 2017

\section{Keywords}

Medicinal properties, Folk and traditional medicines, Plant resources, Ethnomedicinal, Therapeutic value.

\section{Introduction}

Ethnobotany deals with the inter relationship between plants and human beings. Man has been dependent on plants for its various needs like food, shelter, fibers, fodder and medicines etc. Awareness and use of plants for medicinal purposes can be traced since the times immemorial. Use of various plants and their parts for various curative purposes has been well explained in Charak Samhinta and Sushurata Samhinta. Almost every indigenous culture in the world uses plants for medicinal purposes. According to World Health Organization (WHO), almost $80 \%$ of world population is dependent on traditional medicines for their primary health care needs (Pie, 1999; Anonymous, 2000; Hamilton et al., 2003).

In past few decades, due to urbanization, industrialization and advent of modern medicinal systems a somewhat decline in use of traditional medicinal practices was observed. However, recently a major comeback has been made by traditional medicinal systems involving use of plants. Various traditional medicinal systems practicized in India are Ayurveda, Homeopathy, Unani and Siddha system. All of these major alternative medicinal systems use approximately7500 species of plants in their formulations. In addition to above medicinal systems, there is another not so well acknowledged, though common system of medicine-Folk medicinal system. A vast knowledge regarding the use of plants for cure of various ailments accumulate in the areas where use of plants is still of great importance. In India, folk medicinal practitioners, commonly called- Vaidya exclusively depend upon various plants for the preparation of their unique repertoire as remedy for a variety of common as well as chronic ailments. But precisely, it is not only the vaidyas rather the local inhabitants also, who have knowledge of therapeutic values of certain plants growing in an area (Wallis, 1985; Shah, 2005). There has been several reports of 
ethnomedicinal studies from the different parts of the world (Martin, 1983; Gidway et al., 2003; Ahmad, 2007; Sardar et al., 2009; Ali et al., 2012; Uprety et al., 2012) as well as India (Dixit et al., 1984; Jain et al., 2004; Kumar et al., 2015; Shamim et al., 2012; Kaur, 2015). However, it was observed that a very little attention has been paid to the ethnomedicinal aspect of plants growing in Punjab state. Though, there are reports of such studies from the state but to a meager extent. Keeping in view this lacuna, present study was planned as an effort to fill the gap. Punjab is located in the northwest part of India. The climatic conditions of the state are quiet favourable for the growth of a large variety of plants. Various herbs, shrubs and trees growing in Punjab are used for folk medicinal purposes. In the present study, only trees of some ethnomedicinal importance were taken into consideration. Some of the trees are native to the state while others are growing here as a part of ex situ conservation measures.

During the present investigation, ethnomedicinal uses of trees growing in Punjab state were documented. 38 species of trees falling under 35 genera have been included in present study. The documented trees belong to 20 families of angiosperms.

\section{Materials and Methods}

The present study was conducted during 2015-2016.For this purpose, a number of field forays were made to different parts of Punjab state. During these forays, information was gathered regarding various trees growing in the particular area and their use for ethnomedicinal purposes by the local people. A semi structured questionnaire was prepared to document the information acquired from local people including vaidyas and hakims. They were mainly asked about use of particular parts of trees in a particular ailment and mode of administration of such folk medicines. The information gathered was cross checked with the help of reliable literature on ethnobotanical aspects of plants. Collection of various ethnomedicinally important part of trees were made. Plants were identified with the help of Flora of Punjab and other relevant available literature.

\section{Results and Discussion}

During the present study, ethnomedicinally important trees growing in Punjab have been investigated. Use of some of these as folk medicines have been reported previously (Martin, 1995; Aqil et al., 2006; Khan, 2009; Bhattacharya et al., 2014; Sahu et al., 2012;
Mohanapriya et al., 2013; Kaur et al., 2011; Preeti et al., 2014), while most of these have not been investigated earlier from ethnomedicinal point of view. Overall 42 trees have been investigated during the present study. The trees under investigation belong to 38 species falling under 35 genera. These belong to 20 families of angiosperms. Maximum number of trees documented in the study belong to family Fabaceae (Ten), followed by

Rutaceae (Four), Bignoniaceae, Combretaceae, Moraceae, Myrtaceae (Three each), Euphorbiaceae and Meliaceae (Two each), Anacardiaceae, Apocynaceae, Bombacaceae, Moringaceae, Oleaceae, Punicaceae, Rhamnaceae, Rubiaceae, Salvadoraceae, Sapotaceae and Tiliaceae (One each). A plant inventory was prepared on the basis of collected information. The plant species investigated have been arranged family wise. Alphabetical order in the name of family has been is followed for the description of trees under present study. The information regarding the family, botanical name, common/vernacular name of the tree, its part used and its use in traditional medicines has been mentioned in table 1.

A number of trees growing in Punjab state find their uses in folk medicines. Most of these are used for different types of ailments. For this purpose, generally different parts of plant such as roots, bark, leaves, flowers, fruits or seeds are used. These plant parts are used in a variety of traditional formulations in dry, powdered form or in the form of some decoctions. It was observed some of these are used alone while others in combination with other plant sources to improve their therapeutic value. Some of the trees have curative properties against some particular type of ailments, while others have a broad range of such properties i.e., these are used in a variety of different types of ailments. Some of the trees investigated were reported earlier also for their folk medicinal value, while others have not been given due importance from the view point of their use in folk medicines. The indigenous knowledge of various plant resources can be explored on a large scale. However, care should be observed to prevent their overexploitation so that these valuable plant resources may not extinct.

\section{Conclusion}

Man has been dependent on trees for a variety of its needs. Use of plants for cure of different types of ailments has been reported since ancient times. Medicinal plants are precious valuable resources of an area. 
Table.1 A plant inventory arranged in an alphabetical order of the families to which the investigated trees belong, showing botanical name/s of the trees, their common/ vernacular names, parts used for medicinal purposes and their use in folk medicines

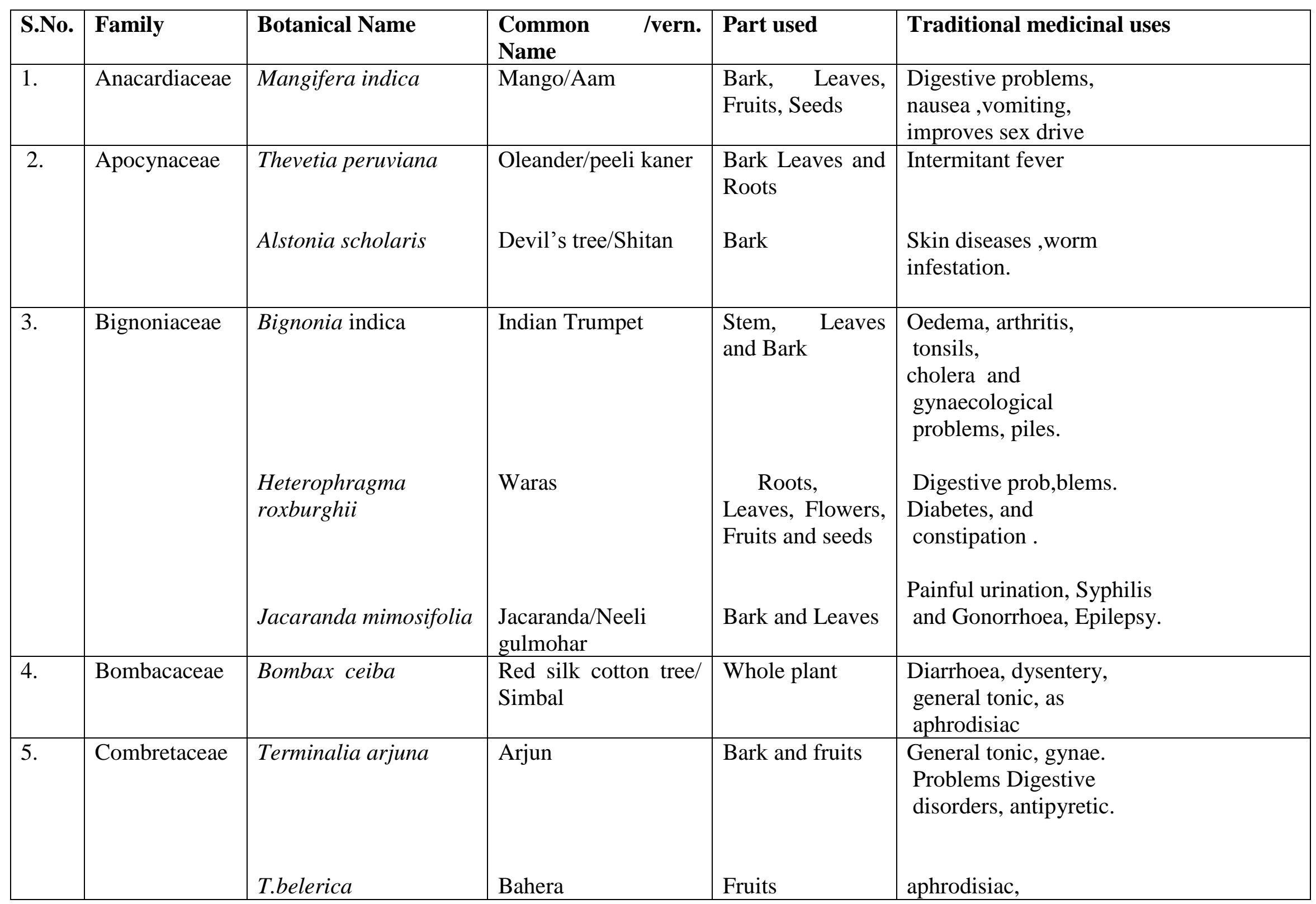




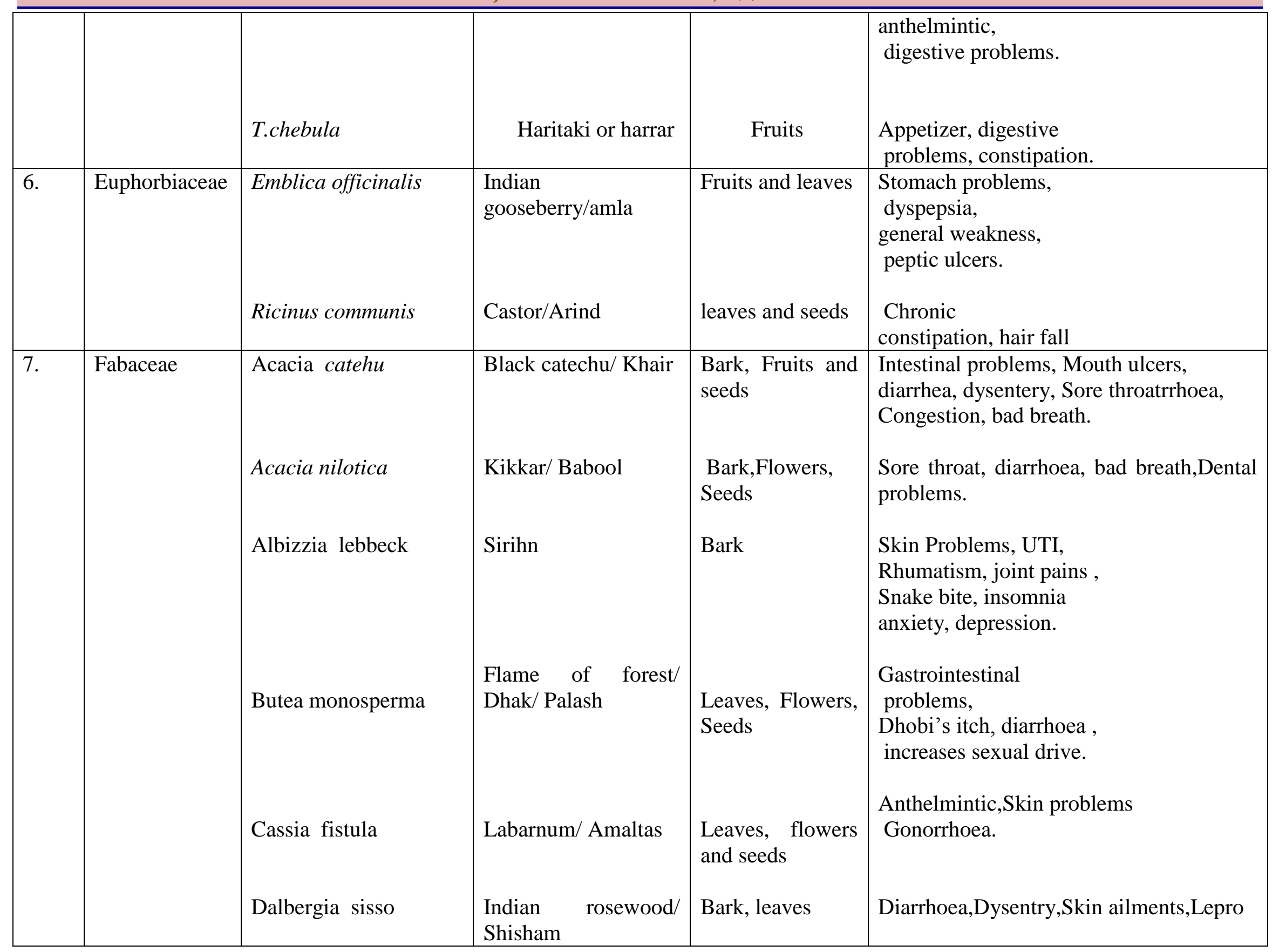




\begin{tabular}{|c|c|c|c|c|c|}
\hline & & $\begin{array}{l}\text { Delonix regia } \\
\text { Pongamia pinnata } \\
\text { Prosopis cineraria } \\
\text { Prosopis juliflora }\end{array}$ & $\begin{array}{l}\text { Gulmohar/Krishan } \\
\text { chura } \\
\text { Karanj } \\
\text { Jandi } \\
\text { Vilayati Kikkar }\end{array}$ & $\begin{array}{l}\text { Bark , Leaves, } \\
\text { Flowers } \\
\text { Whole plant } \\
\text { Bark, leaves, } \\
\text { Flowers } \\
\text { Bark,leaves and } \\
\text { flowers. }\end{array}$ & $\begin{array}{l}\text { Skin disorders, Intermitant fever } \\
\text { Constipation, skin } \\
\text { disorders } \\
\text { Skin problems, Worm } \\
\text { infestation, Digestive } \\
\text { problem, Prevention of miscarriage. } \\
\text { Digestive disorders, } \\
\text { Eye ailments } \\
\text { Prevention of } \\
\text { miscarriage. } \\
\text { Dental problems, } \\
\text { Stomach disorders }\end{array}$ \\
\hline 8. & Lythraceae & Lagerstromeia indica & Crepe Myrtle/ Jarul & $\begin{array}{ll}\text { Bark, } & \text { Flowers, } \\
\text { Leaves } & \end{array}$ & $\begin{array}{l}\text { Constipation, Cuts and } \\
\text { Wounds }\end{array}$ \\
\hline 9. & Meliaceae & $\begin{array}{l}\text { Azadirechta indica } \\
\text { Melia azadirach }\end{array}$ & $\begin{array}{l}\text { Neem } \\
\text { Bead } \\
\text { tree/Dharek/Bakain }\end{array}$ & $\begin{array}{l}\text { Whole plant } \\
\text { Bark, Leaves, } \\
\text { Seeds }\end{array}$ & $\begin{array}{l}\text { Skin ailments, blood } \\
\text { purification } \\
\text { Dental problems, } \\
\text { Stomach } \\
\text { disorders, Diabetes, } \\
\text { Eye problems ,birth } \\
\text { control ,as antiseptic } \\
\text { Leucorrhoea, Piles, skin } \\
\text { infections, bleeding } \\
\text { gums, intermittent } \\
\text { fever }\end{array}$ \\
\hline 10. & Moraceae & $\begin{array}{l}\text { Ficus benghalensis } \\
\text { F. religiosa }\end{array}$ & $\begin{array}{l}\text { Banyan/ Bohar } \\
\text { Peepal }\end{array}$ & $\begin{array}{l}\text { Whole plant } \\
\text { Whole plant }\end{array}$ & $\begin{array}{l}\text { Diabetes, Frequent urination,ria, } \\
\text { diarrhoea and dental problems. } \\
\text { Problems, headache. } \\
\text { Skin problems,Cough and Congestion, } \\
\text { Jaundice ,blood } \\
\text { disorders }\end{array}$ \\
\hline
\end{tabular}


Int.J.Curr.Res.Aca.Rev.2017; 5(3): 11-19

\begin{tabular}{|c|c|c|c|c|c|}
\hline & & Morus alba & "Mulberry/ Shahtoot & Bark and fruits & $\begin{array}{l}\text { Fever, cold ,cough, } \\
\text { dry and } \\
\text { sore eyes, oedema and } \\
\text { premature greying of } \\
\text { hair }\end{array}$ \\
\hline 11. & Moringaceae & Moringa oleifera & Drumstick/Suhanjana & Whole plant & $\begin{array}{l}\text { Stomach disorders, } \\
\text { intestinal spasms, } \\
\text { anaemia, arthritis, } \\
\text { constipation, high B.P., } \\
\text { kidney stone, epilepsy } \\
\text { etc. }\end{array}$ \\
\hline 12. & Myrtaceae & Eucalyptus lanceolata & Safeda & Leaves and bark & $\begin{array}{l}\text { Respiratory disorders as cold,cough, } \\
\text { asthma, relieves } \\
\text { anxiety improve } \\
\text { immunity, } \\
\text { anti inflammatory }\end{array}$ \\
\hline 13. & Oleaceae & $\begin{array}{l}\text { Nyctanthes arbor- } \\
\text { tristis }\end{array}$ & Har-shingar & Leaves & $\begin{array}{l}\text { Chronic fever, arthritis, } \\
\text { sciatica pain }\end{array}$ \\
\hline 14. & Punicaceae & Punica granatum & Pomegranate/Anar & Whole plant & $\begin{array}{l}\text { Digestive disorders, } \\
\text { appetizer, skin } \\
\text { problems, } \\
\text { insomnia, anthelmintic. }\end{array}$ \\
\hline
\end{tabular}




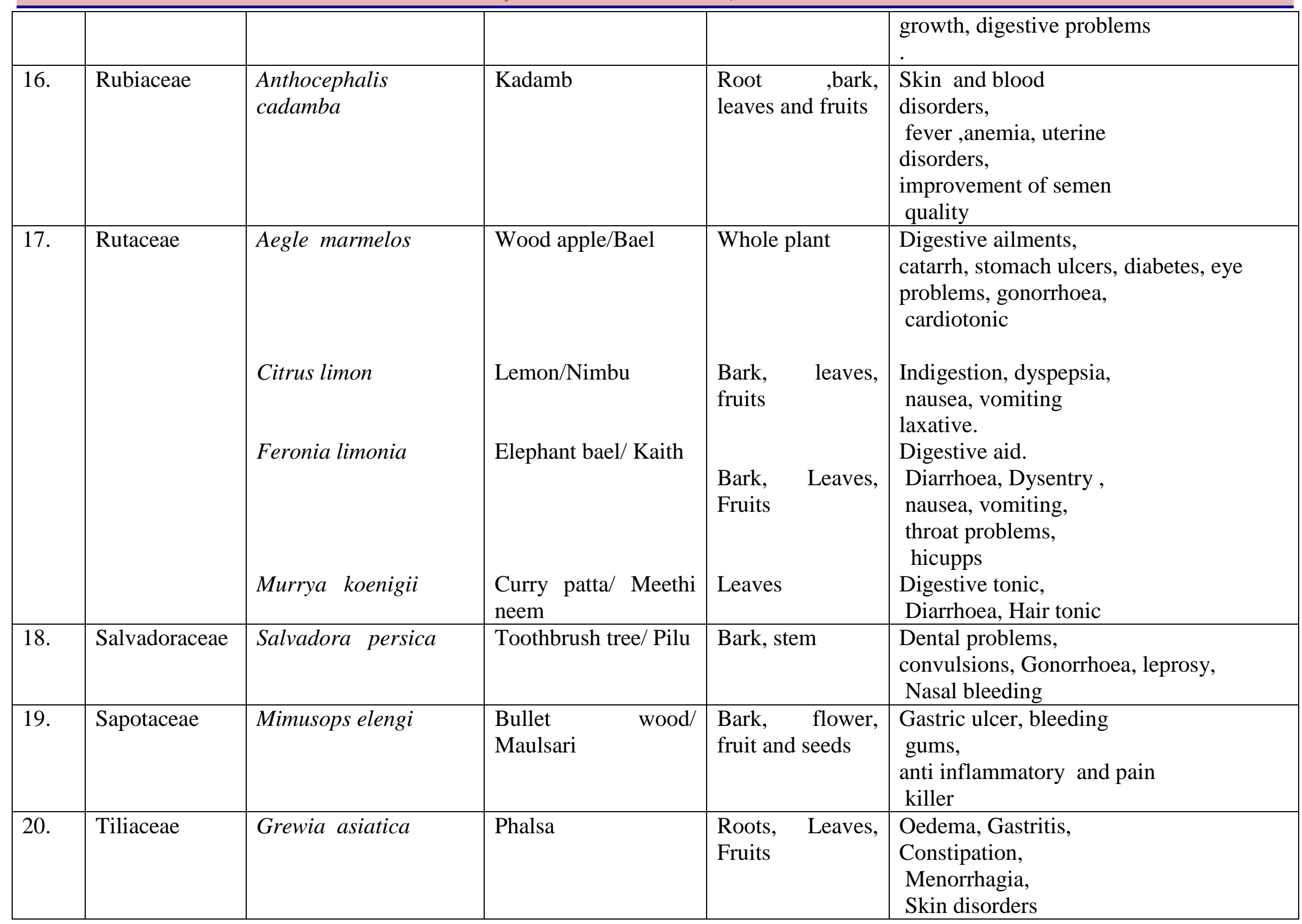


These are not only used by people for curative purposes, but also help to uplift the economic condition of some people, as they earn their livelihood by selling these in market. After receiving a setback for some time, ethnomedicinal importance of plants is emerging as a one of the safe and sustainable approach. However, ethnobotanical awareness among common people will reinforce knowledge and sustainable use of folk medicines and devise methods for transfer of such knowledge to the future generations. Such a system of medicinal treatment upon which majority of population has been relying upon with considerable success should not be overlooked for further medical investigations, especially on those plants which have not been investigated for medical research, although the same have been used by local people over the hundreds of years. In present scenario, a wide potential exists to explore more of ethnomedicinally important plant resources for their therapeutic values.

\section{References}

Ahmad, S.S. 2007. Medicinal wild plant knowledge from Lahore-Islamabad Motorway,(M-2), Pak. J. Bot., 39(2): 355-377.

Ali, A., Akhtar, N., Khan, B.L., Khan, M.S., Rasul, A., Uz-Zaman, S., Khalid, N., Waseem, K., Mahmood, T., Ali, L. 2012. Acacia nilotica: A plant of multipurpose uses. J. Med. Plants Res., 6(9): 14921496.

Anonymous. 2000. General guidelines for methodologies on research and evolution of traditional medicine, WHO/EDM/TRM/2000.Geneva:WHO.

Aqil, F., Ahmad, I., Mehmood, Z. 2006. Antioxidant and Scavenging properties of twelve traditionally used Indian medicinal plants. Turk. J. Biol., 30: 177-183.

Arifa, Z. and Khan, Z.D. 2012. A survey of ethnobotanical important trees of Central Punjab, Pakistan, 58(1,2): 21-30.

Bharath, M., Tulsi, E.L.R., Sudhakar, K., Eshwaraiah, M.C. 2013. Dalbergia sisso DC-An important medicinal plant, Int. J. Res. Pharm. Chem., 3(2): 384-388.

Bhattacharya, M., Singh, A., Ramrakhayani, C. Dalbergia sisso -An important medicinal plant. $J$. Med. Plants Studies, 2: 76-82.

Bussmann, R.W. and Sharon, D. 2006. Traditional plant use in Northern Peru: Tracking two thousand years of health culture. J. Ethnobiol. and Ethnomed., 2: 47.
Choudhary, K., Singh, M., Pillai, U. 2008. Ethnobotanical survey of Rajasthan-An Update. Am. Eur. J. Bot., 1(2): 38-45.

Dangwal, L.R., Singh, T. 2013. Ethnomedicinal study of some forest medicinal plants used by Gujjar tribe of distt. Rajouri (J and K) India Ind.. J. App. Res., 3(3): 11-14.

Dixit, R.S., Pandey, H.C. 1984. Plants used in Folk medicine in Jhansi and Lalitpur section of Bundelkhand, Utter Pradesh. Int. J. Crude Drug Res., 22(1):47-50.

Gidway, M., Afzfwa, Z., Elmqvist, Woldu, Z. 2003. An Ethnobotanical study of Medicinal Plants used by Zay People in Ethopia. J. Ethnopharmacol., 85(1): 43-52.

Hamilton, A.C., Pie, S.J., Kessey, A.A., Khan, S., Lagos, W. and Shinwari, Z.K. 20003. The purpose and teaching of applied ethnobotany. People and Plants Working Paper, 1-76.

Jain, A., Katewa, S.S., Chaudhary, B.L. and Galav, P. 2004. Folk herbal medicines used in birth control and sex diseases by tribes of southern Rajasthan. Indian J. Ethnopharmacol., 90:171-177.

Jain, V., Momin, M., Laddha, K. 2012. Murrya koenigii: An Updated Review. Int. J. Ayur. Medicin. Med., 2(4): 607-627.

Kaur, A., Rana, A.C., Tiwari, V., Sharma, R., Kumar, S. 2011. Review on ethnomedicinal and pharmacological properties of Ficus religiosa. J. Appl. Pharma Sci., 1(8): 6-11.

Kaur, R. 2015. Ethnobotanical studies of some of the traditionally important medicinal plants of Punjab, India. Int. Curr. Res. Aca. Rev., 3(5): 262-271.

Khan, K.H. 2009. Roles of Emblica officinalis in medicine-A Review. Botany Res. Int., 2(4): 218228.

Khare, C.K. 2007. Indian medicinal plants, Springer Publication, New Delhi, pp308.

Kharkonger, P., Joseph, J.A. 1997. Folklore medicobotany of rural Khasi and Jaintia tribes in Meghalaya: Contributions to Indian Ethnobotany (ed. Jain S.K.) Scientific Publishers, Jodhpur, 195208.

Kumar, N., Wani, Z.A., Dhyan, S. 2015. Ethnobotanical studies of plants used by local people of Gulmarag and its allied areas, Jammu and Kashmir, India. Int. J. Curr. Res. Bio. Sci. Plant Biol., 2(9):16-23.

Mahmood, T., Shah, A. 2009. Medicinal Plants used by Traditional Healers in Poonch distt. Of Jammu and Kashmir, 2009; J. Life Sci. Leaflets, 5: 53-60.

Martin, A.J.S. 1983. Medicinal plants in central Chile. Econ. Bot., 37(2): 216-217. 
Martin, G.J. Ethnobotany: A Methods Manual, Chapman and Hall, London.

Mohanapriya, M., Ramaswamy, L., Rajendran, R. 2013. Health and medicinal properties of Lemon(Citrus limon). Int. J. Ayur. Herb Med., 3(1): 1095-1100.

Patil, V.V., Patil, V.R. 2010. Ficus benghalensis Linn.An Overview. Int. J. Pharma Biol. Sci., 1(2): 1-11.

Pie, S.J. 1999/ Ethnobotany and sustainable use of plant resource in $\mathrm{HKH}$ mountain region. Planning workshop on Ethnobotany and its application to conservation and community development in Hindukush Himalayan region, Nepal. Nepal Biol. Conser., 63(3): 205-210.

Preeti, Tripathi, S. 2014. Zizyphus jujube: A pharmacological review. Int. J. Res. Dev. Pharm. Life Sci., 3(3): 959-966.

Qureshi, R.A., Ghufran, M.A. 2007. Indigenous knowledge of Selected Medicinal Wild Plants of Distt. Attock Punjab, Pakistan. Pak. J. Bot., 39(7): 2291-2299.

Sahu, G., Gupta, P.K. 2012. A review of Bauhinia variegata Linn.. Int. Res. J. Pharm., 3(1): 48-51.
Sarad, S., Sharma, A., Kumar, N. 2017. Distribution, diversity, indigenous use and its utilization of ethnomedicinal flora of Rajouri, Jammu and Kashmir, India. Int. J. Life Sci. Scienti. Res., 3(1): 820-827.DOI:1021276/ijlssr.2017.3.1.12.

Sardar, A.A. and Khan, Z. 2009. Ethnomedicinal studies on plant resources of the. Shakargarh, Distt. Narowal, Pakistan Pak. J. Bot., 41(1): 11-18.

Shah, N.C. 2005. Ethnobotany and indigenous knowledge in Indian context, 17(1, 2): 64-70.

Shamim, A.A., Shah, A. 2012. Some ethnomedicinal plants of Distt. Rajouri (Jammu Province) India. Indian J. L. Sci., 2: 47-49.

Sharma, G.N., Dubey, S.K., Sharma, P., Sati, N. 2011. Medicinal values of Bael (Aegle marmelos) (L) Corr.: Review. Int. J Curr. Pharmaceut. Rev Res., 1(3): 12-22.

Uprety, Y., Asselin, H., Dhakal, D., Julien, N. 2012. Traditional uses of medicinal plants in boreal forest of Canada: Review and Prospects. J. Ethnobiol. Ethnomed., 8: 7.

Wallis, T.E. 1985. A text book of pharmacognosy, New Delhi: CBS Publisher and distributer; pp104.

\section{How to cite this article:}

Geetanjli. 2017. Ethnomedicinal Studies of Some Trees Growing in Punjab State. Int.J.Curr.Res.Aca.Rev. 5(3), 1119. doi: https://doi.org/10.20546/ijcrar.2017.503.002 